\title{
Comment
}

\section{Is the State of Georgia in the Fifth Circuit?}

The Luce Professor of Jurisprudence at Yale and one of the puisne judges of the United States Court of.Appeals for the Second Circuit, also sometime Nash Professor of Law at Columbia University, were discussing the allocation of judicial business among the several circuits. In the course of discussion, the judge made the unqualified assertion that "the State of Georgia is in the Fifth Circuit," a statement controverted by his colloquist. This difference of view resulted in a wager of 5 cents. The judge's sub. sequent letter of demand met with the reply set forth below.

November 15, 1971

The Honorable Paul R. Hays

Circuit Judge

The United States Court of Appeals

for the Second Circuit

United States Court House

Foley Square

New York, New York

My dear Judge Hays:

I have your letter regarding the question of the inclusion of the State of Georgia in the Fifth Circuit. Without any disrespect (andl how much less resentment!) I have to note that you rest your case solely on (uncited) authority, opening no chink through which light might come regarding its rational ground. Candidly, you have given me little to answer. I can, therefore, advance the question only by stating my own views at large, hoping thereby to produce (as it were by an intellectual Gegenschein) some clarity in your own.

I must begin by avowing that I simply cannot, after much thought, find any meaning in the proposition, "The State of Georgia is within the Fifth Circuit."

The expression, "The State of Georgia," may bear and has bornc three distinct meanings: (I) a certain part of the earth's surface, as 
conventionally bounded by cartographers; or (2) the political structure conventionally known by that name; or (3) the residents of that territory. This triple ambiguity is not of modern making; it roots in the very language of the Constitution. It cannot and perhaps should not be resolved; quid a majoribus confusum est, sit confusum in aeternitatem!

The point here is that its resolution is unnecessary to a determination of the issue that divides us, for on none of the three semantic branches is it meaningful, or (insofar as cloudily meaningful) true, to say that the State of Georgia is "within" the Fifth Circuit. As to the first meaning, in what sense can a savannah, a hillock or a bayou be said to be "within" a judícial circuit? The concretenesses of territory and the abstractions of appellate jurisdiction (like butterflies and bons mots) appertain to different orders of being; the relationship of inclusion is, between them, quite devoid of possible referent. (This so thoroughly covers the ground that I shall refrain from refreshing your memory as to the chariness with which federal courts approach ordinary questions of title to land.)

As to the second branch, argument seems hardly necessary. Calhoun or no Calhoun, the political structure known as "The State of Georgia" is in no sense and in no way encompassed "within" the appellate power of the Fifth Circuit. There is one relation and one only: the Fifth Circuit Court of Appeals may Glendoweranly ask the Supreme Court of Georgia a question. To characterize such a relation as one of "inclusion" strains language far past the breaking-point.

As to the third branch, is it not a terminological absurdity to say of each Georgia artisan, of each Georgia field-hand, of every Georgia housewife, that he or she is "within" the Fifth Circuit? Most of Georgia's inhabitants have never been and never will be involved in litigation in the federal courts. As well say of a man who never uses snuff that he is "within" the snuff factory that supplies the surrounding territory. Besides, the appellate jurisdiction of the Fifth Circuit Court of Appeals is by no means limited to cases involving Georgia citizens, or citizens of any State or group of States. A Fijian or a citizen of Chad may plead through counsel at its bar, quite as well as the oldest living inhabitant of Macon, or, for that matter, Augusta.

I conclude, therefore, that in no possible sense may one meaningfully say that Georgia is within the Fifth Circuit.

You refer to authorities, however, and (in absence of citations) I must conclude that you have consulted authorities of the same calibre as the ones I have sought out. I readily concede that many (if not 
all) such authorities do loosely assert that Georgia is in the Fifth Circuit. I have had, perhaps, more time than your busy life has left to you to cross-examine these "authorities," and I find that they are, one and all, making this assertion in the quite inadmissibly loose sense that often (though by no means always) the judgments of the United States District Courts sitting in Georgia (in the first of the senses above) are reviewable on appeal by the United States Court of Appeals for the Fifth Circuit. I need hardly point to the looseness of this assertion for you to reject it as inadequate or worse, where it is "inclusion" of a State that is in controversy.

This assertion is, however, commonly made, in this very loose sense, and my researches lead me to think it true, as a matter of current practice. I believe I have said enough to show that it is also quite irrelevant. But even its truth in practice is, in my view, the result of an arid formalistic approach to the subtle task of statutory construction.

It is true that, as a matter of mere words, divorced from historical context, Congress might be thought to have placed Georgia (in this inartful, colloquial sense) "in" the Fifth rather than "in" the Fourth Circuit. But a single step away from this life-killing literalism leads to a contrary result. And I have little doubt that the Supreme Court, were the case properly briefed and argued, would so decide.

What is the Congressional plan of division between these circuits? What is Congress' overriding intent? When I say "Texas, Florida, Alabama, Mississippi and Louisiana" on the one hand, and, on the other, "South Carolina, North Carolina, Virginia and Maryland," does not that intent leap to the eye? Beyond any doubt, what Congress meant to do was to place "in" the Fourth Circuit States forming part of the original Union, and "in" the Fifth Circuit States acquired by the great territorial accessions of the early decades of the last century. Do not all men know that a general difference in manners and morals divides these groups of states-that one group is marked by the gentility of long civilization, and that the other was, until a historical yesterday, frontier? Can one doubt that Congress, in the broadest sense, intended to respect and follow the line history so clearly had drawn?

All this is beyond doubt. The narrow issue remaining is whether a mere verbal inadvertence in the execution of a plainly visible plan is to be allowed to frustrate the plan itself. Are we to say to Congress, "We see clearly enough what you were trying to do, but you have clumsily chosen words not quite apt for doing it"? I cannot think we will do that. And if we do not, where does Georgia belong? Where is Georgia, under the statute properly read? 
Is the State of Georgia in the Fifth Circuit?

(Generally on this latter point, see the opinion of the Court in Calbeck v. Travelers Ins. Co., 370 U.S. 114 [1962].)

While I am not unwilling to hear further argument, I must confess I think it unlikely to rise to refutation of the foregoing. Meanwhile, though the amount is trivial, I cannot, for reasons of principle, comply with your request.

Very respectfully,

Charles L. Black, Jr.

Luce Professor of Jurisprudence Yale Law School 